\title{
KONSEP TEOLOGI INJILI TENTANG ROH ORANG MATI
}

\author{
Decky Krisnando, Enggar Objantoro, \& I Putu Ayub Darmawan \\ Sekolah Tinggi Teologi Simpson \\ Jl. Agung No. 66, Krajan, Kel. Susukan, Kec. Ungaran Timur, Kab. Semarang, Jawa Tengah \\ Email: deckykrisnando19@gmail.com
}

\begin{abstract}
Decky Krisnando, Enggar Objantoro, \& I Putu Ayub Darmawan, The Consept of Evangelical Theology About the Spirit of Death People. This article is a library research which describe the evangelical theology about the spirit of death people. To describe the theology, researcher make a research from the relevan books resources concerning the topic, in which it is analyzed in order that found the relation among them. After that, the researcher make a conclusion systematically. From the research, Evangelical theology about the spirit of death people is in the different dimension when he is life. For the death, there are just two possibilities to go in the heaven or in the hell. For the people who believe in God, he will go to the heaven, but the people who does not believe in God, he will go to the hell. The existence in the heaven and the hell is everlasting. The spirit which is in the heaven, will live together with God in eternity. For the unbeliever, they will be punished in the hell forever.
\end{abstract}

Keywords: Spirit, the Dead, Evangelical Theology.

\begin{abstract}
Abstrak: Decky Krisnando, Enggar Objantoro, \& I Putu Ayub Darmawan, Konsep Teologi Injili Tentang Roh Orang Mati. Artikel ini merupakan sebuah penelitian pustaka yang memaparkan tentang konsep teologi Injili tentang roh orang mati. Untuk memaparkan konsep tersebut, penulis mencari berbagai informasi dari sumber pustaka relevan terkait topik penelitian yang kemudian dianalisis sehingga dapat ditemukan keterkaitan dan peta konsepnya dan akhirnya merumuskan konsep penulis secara sistematis dan dipaparkan secara deskriptif. Dari penelitian yang dilaksanakan, konsep teologi Injili tentang roh orang mati ada dalam dimensi yang berbeda dengan ketika ia ada di dunia ini. Hanya ada dua kemungkinan bagi jiwa/roh orang mati yaitu masuk dalam sorga atau neraka. Bagi orang yang percaya Kristus maka jiwa/rohnya akan masuk dalam sorga yang mulia. Sebaliknya bagi orang yang tidak percaya Kristus, jiwa/rohnya akan masuk neraka. Keberadaan di sorga dan neraka sifatnya kekal. Jiwa/roh yang masuk sorga akan mengalami kemuliaan bersama dengan Allah kekal, selama-lamanya. Begitu juga, jiwa/roh yang masuk neraka, akan mengalami penghukuman, yang tidak berkesudahan, selama-lamanya.
\end{abstract}

Kata kunci: Roh, Orang Mati, Teologi Injili.

\section{PENDAHULUAN}

Manusia adalah makhluk hidup yang diciptakan oleh Allah dengan sangat baik (Kej. 1:31). Allah menciptakan manusia dengan memiliki tubuh dan roh. Tubuh merupakan wujud dari diri manusia yang kelihatan, sedangkan roh tidaklah dapat dilihat secara manusiawi. Tubuh manusia memiliki keterbatasan, karena tubuh manusia yang kelihatan akan mengalami kematian. Dalam Matius 6:25, Tuhan Yesus mengatakan bahwa “... janganlah kuatir pula akan tubuhmu ... bukankah hidup itu lebih penting dari pada makanan dan tubuh itu lebih penting dari pada pakaian." Hal ini menunjukkan bahwa Tuhan Yesus sendiri mengakui adanya tubuh pada diri ma- nusia. Dalam Alkitab dijelaskan bahwa orang yang mati akan meninggalkan kehidupan di dunia ini (Kej. $23: 2 ; 25: 8)$. Selain itu, kematian adalah suatu peristiwa yang tidak dapat dilawan oleh manusia, karena semua manusia pasti akan mengalami kematian (Pkh. 8:8). Kematian juga dilukiskan sebagai Allah mengambil jiwa, sebab Tuhan Yesus mengatakan dalam Lukas 12:20, “... Hai orang bodoh, pada malam ini juga jiwamu akan diambil dari padamu,..."

Setiap manusia pasti mengalami kematian, karena manusia adalah makhluk yang diciptakan. Oleh karena manusia adalah makhluk ciptaan, sehingga manusia memiliki keterbatasan, yaitu bisa mengalami kematian. Akan tetapi, kematian yang 
dialami oleh manusia ialah kematian tubuh (fisik). Kematian adalah suatu keadaan yang tidak bisa diketahui dan tidak bisa direncanakan oleh manusia, karena kematian itu akan terjadi saat yang tidak diketahui manusia dan setiap manusia pasti mengalaminya. Mengenai kematian manusia, hanya Tuhan yang tahu, kapan manusia itu mati atau kapan manusia itu hidup. Sehingga hidup manusia di dunia ini hanya dalam jangka waktu yang terbatas, sebab apabila orang mengalami kematian hal itu berarti segala kehidupannya di dunia ini lenyap. Dalam Pengkhotbah 9:10 dituliskan bahwa, “...tak ada pekerjaan, pertimbangan, pengetahuan dan hikmat dalam dunia orang mati...."

Jadi, dapat dipahami bahwa kematian jasmani merupakan akhir dari hidup di dunia ini karena segala aktivitas, hubungan dengan keluarga dan orangorang akan berakhir. Selain itu, usia/umur menjadi suatu ukuran bagi manusia, sehingga manusia mengalami kematian. Dalam Alkitab, umur/usia manusia sering digunakan saat menyampaikan tentang kematian seseorang (bnd. Kej. 5:5-31; 9:29; 11:32; 25:8; dll.). Ayat-ayat tersebut merupakan suatu bagian yang menceritakan tentang kematian para tokoh-tokoh Alkitab.

Dari beberapa kisah yang ada, dapat dipahami bahwa umur/usia yang terbatas pada manusia yang membuat ia mengalami kematian fisik. Selain itu, Kejadian 6:3 dituliskan bahwa: "Roh-Ku tidak akan selama-lamanya tinggal di dalam manusia, karena manusia itu adalah daging, tetapi umurnya akan seratus dua puluh tahun saja." Daging (tubuh manusia) bukanlah bersifat kekal, sehingga daging (tubuh manusia) dapat mati. Sehingga dapat dipahami bahwa manusia dapat menggalami kematian jika rohnya diambil oleh Allah dari pada tubuh.

Bangsa Israel merupakan bangsa pilihan Allah dan Allah ingin bangsa Israel hidup kudus dan hidup takut akan Dia. Oleh karena itu Allah memberikan berbagai perintah untuk ditaati dan lakukan oleh bangsa Israel, salah satunya ialah bangsa Israel diperintahkan oleh Allah untuk tidak menajiskan diri dengan bertanya kepada para peramal atau arwah orang mati. Allah memberi perintah kepada bangsa Israel sebagaimana yang tercatat di dalam Imamat 19:31 yaitu, "Janganlah kamu berpaling kepada arwah atau kepada roh-roh peramal; janganlah kamu mencari mereka dan dengan demikian menjadi najis karena mereka; Akulah TUHAN, Allahmu." Ayat ini tegas memberikan perintah kepada bangsa Israel agar tidak 'berpaling' dan 'mencari' roh peramal, karena roh peramal atau roh orang mati adalah seorang yang berkomunikasi atau mencari petunjuk (tanda) kepada arwah (roh orang mati).

Setiap orang pasti memiliki pandangan tersendiri tentang roh orang mati, dan setiap orang juga pasti mengenal yang namanya "roh-roh orang mati", apalagi bagi daerah-daerah yang okultismenya masih kental. Sehingga, ada daerah yang masih mempercayai adanya roh orang mati. Ada beberapa suku yang budaya atau tradisinya masih kuat mempercayai roh orang mati. Selain itu ada orang-orang Kristen dalam suku tertentu maupun budaya tertentu yang masih mempercayai adanya roh orang mati yang bergentayangan.

Keyakinan-keyakinan akan adanya roh orang mati merupakan sesuatu yang sangat luas, karena setiap daerah atau setiap orang memiliki pandangan dan keyakinan tersendiri mengenai roh orang yang sudah mati/meninggal. Kematian seseorang biasanya dipandang sebagai suatu peristiwa yang menyedihkan bagi sanak keluarga yang ditinggalkannya.

Kruyt dalam bukunya (2008, p. 70) menceritakan tentang keyakinan suku Poso terhadap roh orang mati. Suku Poso meyakini bahwa, “...setiap orang akan bertemu dengan saudaranya yang telah meninggal dan orang yang mengalami itu tidak akan mengalami kematian, tetapi langsung beralih ke alam bahagia." Suku Poso percaya bahwa orang mati akan mendapat perhentian bersama dengan saudara-saudaranya, dan akan menikmati kebahagiaan. Dengan demikian, roh orang mati itu tidak bergentayangan, sebagaimana keyakinan suku-suku lain, tetapi roh orang mati itu pindah kepada suatu alam lain yaitu alam bahagia. 
Sedangkan dalam budaya Batak Toba, meyakini bahwa roh orang mati itu akan berubah menjadi hantu, seperti penjelasan Walangare (2016, p. 68):

Dalam budaya Batak juga ada pemahaman bahwa orang yang meninggal itu dikatakan dengan "Na dialap ompungna do $i$ ". Dengan anggapan ini, maka orang Batak mengatakan "martondi na mangolu,marbegu na mate” (yang masih hidup memiliki roh dan yang telah mati menjadi hantu). Hal inilah dijelaskan karena orang $\mathrm{Ba}-$ tak percaya bahwa jika seseorang telah meninggal, maka "daging gabe tano, hosa gabe alogo, tondi gabe begu" (daging jadi tanah, nafas jadi angin, roh jadi hantu).

Dengan kata lain, roh orang mati berubah menjadi hantu, yang dapat mengganggu orang yang masih hidup.

Dalam kepercayaan orang Toraja, terdapat upacara Ma'badong. Menurut Salam (2017),

Ma'badong adalah suatu bentuk tarian dan nyanyian tanpa diiringi alat musik, mendeklamasikan syair-syair pujian mengenai orang yang telah meninggal, ataupun ratapan-ratapan kesedihan dari pihak yang ditinggal.

Upacara tersebut dahulu dilaksanakan untuk mendoakan roh orang mati yang menuju 'Puya' dan memperoleh keselamatan (Lakburlawal, 2017).

Kemudian dalam penelitian yang dilakukan oleh Tago'a dan Enoh (2010, p. 27) menjelaskan sebuah keyakinan pada orang Pamona di Kabupaten Luwu Timur Propinsi Sulawesi Selatan. Dalam jurnalnya dijelaskan bahwa apabila seorang ibu meninggal saat melahirkan, maka orang Pamona meyakini jika roh ibu tersebut akan menjadi renggeana ("mama" dan "ana" artinya "anak") dan pada malam harinya roh tersebut akan bergentayangan untuk mengganggu atau mengejar orang-orang yang sedang berjalan di malam hari. Dampaknya adalah apabila ada ibu yang meninggal karena melahirkan maka malam harinya jarang ada yang keluar.

Beberapa informasi di atas menunjukkan bahwa terdapat berbagai keyakinan di berbagai suku tentang roh orang mati. Hanya dalam konteks gereja Injili atau teologi Injili, perlu dilakukan kajian untuk memahami konsep tentang roh orang mati.
Dari latar belakang di atas maka rumusan masalah dalam penelitian ini adalah bagaimana konsep teologi Injili tentang roh orang mati? Adapun tujuan dari penelitian ini adalah untuk mendeskripsikan atau memaparkan konsep teologi Injili tentang roh-roh orang mati.

\section{METODE}

Penelitian ini adalah penelitian teologi yang melakukan sebuah kajian pustaka tentang konsep teologi Injili tentang roh orang mati. Sumber-sumber literatur dari kaum Injili yang penulis gunakan untuk memaparkan tentang konsep teologi Injili tentang roh orang mati adalah karya Mc Candlish Phillips dengan judul Dunia Roh, A.C. Kruyt dengan buku berjudul Keluar Dari Agama Suku Masuk Ke Agama Kristen, Volkhard Scheunemann dengan buku berjudul Dunia Orang Mati. Kemudian penulis menggunakan beberapa buku teologi sistematika yang membahas topik terkait. Beberapa sumber pustaka yang penulis gunakan adalah karya Paul Enns dengan buku berjudul The Moody Handbook Of Theology, Brill, J. Wesley dengan judul buku Dasar Yang Teguh, Anthony A. Hoekema dengan buku berjudul Manusia: Ciptaan Menurut Gambar Allah, Cornelius Plantinga Jr yang membahas tentang Jaminan Iman: Devosi Pembangunan Iman, Henry C. Thiessen dengan judul buku Teologi Sistematika, dan Peter Wongso dengan judul buku Dasar Iman Kepercayaan Kristen. Penulis juga menggunakan sumber-sumber pustaka yang telah terpublikasi terutama jurnal-jurnal teologi sebagai sebuah pembahasan mendalam.

Proses analisis yang penulis lakukan adalah 1) mencari berbagai informasi dari sumber pustaka relevan terkait topik penelitian, kemudian menemukan keterkaitan dan peta konsep dari beberapa sumber; 2) selanjutnya penulis juga melakukan studi kata terhadap beberapa istilah dalam Alkitab yang terkait dengan topik penelitian; 3) merumuskan konsep penulis berdasarkan konsep yang dikemukakan dalam beberapa sumber pustaka; 4) memaparkan secara sistematis hasil rumusan konsep secara deskriptif. 


\section{HASIL DAN PEMBAHASAN}

\section{Makna Kata Roh Dalam Alkitab}

Dalam Alkitab, kata 'Roh' pertama kali disebutkan menunjuk pada Allah. Dalam Kejadian 1:2, "... dan Roh Allah melayang-layang di atas permukaan air." - kata 'Roh' dalam ayat ini ialah "ruakh", penggunaan kata tersebut lebih menunjuk kepada Allah. Dyrness (2013, p. 75) menjelaskan bahwa kata ruakh muncul 389 kali, lebih sering dipergunakan untuk Allah dan ruakh adalah napas yang Tuhan berikan kepada umat manusia (Yes. 42:5). Lebih lanjut Dyrness (2013, p. 75) dalam bukunya mengatakan bahwa, "Roh dipakai untuk Allah guna menunjukkan kekuasaan-Nya yang besar. Oleh Roh-Nya ("napas") bumi diciptakan (Mzm. 33:6)."

Selain itu, dalam Perjanjian Lama, 'roh' sering diartikan sebagai 'angin' atau 'nafas' (Kej. 6:17). Jika dilihat dari awal penciptaan, manusia diciptakan oleh Allah dengan "menghembuskan nafas hidup", sehingga manusia itu menjadi makhluk hidup. Kejadian 2:7 menuliskan bahwa, "ketika itulah TUHAN Allah membentuk manusia itu dari debu tanah dan menghembuskan nafas hidup ke dalam hidungnya; demikianlah manusia itu menjadi makhluk yang hidup." Penggunaan kata "nafas" dalam Kejadian 2:7 ialah $\mathrm{hm}$ * ${ }^{\mathrm{H}}+$ (neshamah, 5397) atau dalam bahasa Inggris spirit. Spirit artinya roh, jiwa atau arwah dan dalam arti yang lebih luas, spirit juga adalah jin, hantu, atau makhluk halus (Strong, 1980).

Akan tetapi, sesuai dengan konteks ayat ini, arti kata 'spirit' lebih merujuk kepada 'roh manusia', sebab dipahami bahwa Kejadian 2:7 menjelaskan tentang keadaan manusia yang memiliki keterbatasan, sehingga Allah yang bertindak untuk memberikan kehidupan atau 'nafas' kepada manusia sehingga manusia dapat menjadi makhluk yang hidup.

Oleh karena manusia diciptakan oleh Allah dengan adanya roh atau napas, sehingga dapat dipahami bahwa dalam diri manusia terdapat roh atau napas yang memberikan kehidupan dan membuat manusia menjadi makhluk yang hidup. Philips (1972, p. 128) menjelaskan:
Roh ialah inti dari manusia. Di dalam roh ini manusia mempunyai kemampuan yang diberikan oleh Allah berhubungan dengan Allah; yang adalah Roh, dan yang harus disembah dalam roh dan kebenaran, Roh merupakan tempat yang suci dimana kehidupan rohani dijalani.

Meskipun manusia diciptakan oleh Allah dengan adanya roh dalam diri manusia, penting juga untuk diketahui bahwa, "Manusia adalah satu ciptaan sekaligus satu pribadi; ia adalah pribadi yang diciptakan." (Hoekema, 2003, p. 8).

Jika dikatakan satu pribadi, maka manusia merupakan suatu makhluk hidup yang diciptakan dengan adanya kehendak untuk bertindak, inilah yang dikatakan kehendak bebas manusia sebagai ciptaan. Selain itu, manusia diciptakan oleh Allah dengan adanya tubuh (fisik). Namun, tubuh bersifat fana, karena saat mengalami kematian tubuh manusia akan kembali menjadi debu dan tanah, karena dalam Kejadian 3:19 mengatakan bahwa, “... dengan berpeluh engkau akan mencari makananmu, sampai engkau kembali lagi menjadi tanah, karena dari situlah engkau diambil; sebab engkau debu dan engkau akan kembali menjadi debu."

Dalam kitab Injil Sinoptik, sebutan roh lebih banyak disebutkan menujuk pada 'roh-roh jahat'. Namun, ada beberapa sebutan 'roh' yang menujuk kepada roh manusia. Dalam kitab Injil Sinoptik kata "pneuma" (Yunani) menujuk kepada roh manusia, karena dalam Lukas 8:55 mengatakan bahwa, "Maka kembalilah roh anak itu dan seketika itu juga ia bangkit berdiri. Lalu Yesus menyuruh mereka memberi anak itu makan." Penggunaan kata "roh" dalam ayat ini ialah pneuma, yang artinya angin atau nafas. Jadi, dari beberapa uraian di atas dapat dipahami bahwa roh itu dapat memberikan kehidupan bagi manusia. Selain itu, jika dilihat dari kisah dalam Lukas 8:55, setelah roh anak itu kembali ke dalam tubuhnya, ia mengalami perubahan yaitu hidup kembali. Dalam hal ini Tuhan Yesus menunjukkan bahwa Ia berkuasa atas roh-roh orang mati, karena Ia dapat memanggil roh kembali ke dalam diri manusia.

Dalam Perjanjian Lama, larangan untuk berhubungan dengan roh-roh orang mati (arwah) dan 
peramal sudah ditegaskan: "Janganlah kamu berpaling kepada arwah atau kepada roh-roh peramal...." (Imamat 19:31). Dalam Strong (1980), "kata 'arwah' dalam bahasa Ibrani ialah boa (yôwb, 178) yaitu yang dikenal dengan roh. Kata ini menunjukkan kepada roh-roh orang yang sudah mati. Sedangkan 'roh-roh peramal' dalam bahasa Ibrani ialah ynu Qy! (yiddeoniy, 3049) atau "wizard" (bahasa Inggris) artinya penyihir dan kata tersebut berasal dari kata 7 ' (yâda', 3045) yang berarti mengetahui, mengenal atau mengerti. Kata ini menunjukkan kepada orangorang yang berhubungan dengan roh-roh orang mati, untuk meminta petunjuk, kekuatan, dll.

Jadi, pada masa Perjanjian Lama, penggunaan kata 'roh-roh peramal' menunjukkan pada seorang penyihir, karena pada masa itu seorang penyihir diyakini dapat mengetahui atau mengerti tentang peristiwa yang akan terjadi. Musa mengingatkan kepada bangsa Israel untuk tidak mencari petunjuk atau bertanya kepada roh orang mati melalui peramal, karena Allah sendiri tidak menginginkan hal tersebut, sehingga diperingatkan dalam Imamat 20:6 bahwa, "Orang yang berpaling kepada arwa atau kepada roh-roh peramal, ... Aku sendiri akan menentang orang itu dan melenyapkan dia dari tengah-tengah bangsanya." Jadi, jelas Allah melarang bangsa Israel untuk percaya atau mencari petunjuk pada roh orang mati, karena orang yang berbuat demikian sama halnya tidak percaya kepada Allah.

Paterson (2011, p. 267) mengatakan dalam bukunya bahwa, "Suatu kebiasaan orang-orang Kanaan yang lain yang dilarang di sini, yaitu konsultasi dengan orang-orang mati yang dianggap sanggup meramalkan peristiwa-peristiwa pada masa depan." Sebagaimana yang diuraikan oleh penulis di atas bahwa para peramal lebih dikenal dengan sebutan penyihir atau ahli sihir, karena pada masa itu diyakini bahwa penyihir atau ahli sihir bisa mencari kekuatan atau bimbingan dari alam gaib (dunia orang mati) atau melalui kegiatan kuasa Iblis.

Pada masa Perjanjian Lama, Raja Saul merupakan seorang Raja yang ditentang oleh Allah ka- rena menemui seorang perempuan pemanggil arwah. Dalam 1 Samuel 28:8 mengatakan bahwa;

Lalu menyamarlah Saul, ia mengenakan pakaian lain dan pergilah ia dengan dua orang. Ketika mereka pada waktu malam sampai kepada perempuan itu, berkatalah Saul: "Cobalah engkau menenung bagiku dengan perantaraan arwah, dan panggillah supaya muncul kepadaku orang yang akan kusebut kepadamu."

Setelah kematian Samuel, Saul mengalami tekanan oleh karena bangsa Filistin menyerang bangsa Israel, "Ketika Saul melihat tentara Filistin itu, maka takutlah ia dan hatinya sangat gemetar" (1 Sam. 28:5). Oleh karena keadaan yang membuat ia takut, sehingga Saul berusaha mencari seorang peramal atau seorang ahli sihir. Tujuannya ialah supaya dapat memanggil arwah Samuel yang baru saja mati dan mencari petunjuk dari padanya. Akan tetapi, yang datang kepada Saul bukanlah roh Samuel, melainkan roh jahat (bdk. 1 Samuel 16:14).

\section{Konsep Teologi Injili Tentang Keadaan Roh Orang Mati}

\section{Konsep Kematian}

Kematian merupakan suatu peristiwa yang tidak bisa dihindari oleh manusia, karena semua manusia pasti akan mengalaminya. Hal ini juga dikatakan oleh Hunt (1987, p. 22) dalam bukunya bahwa, kematian merupakan sebuah pengalaman yang luar biasa sulit dihadapi dan tidak dapat dihindarkan. Kematian merupakan suatu pengalaman yang sulit dihadapi, karena kematian tidaklah mengenal waktu atau tempat, artinya setiap manusia, kapan, dimana dan siapa saja pasti akan mengalami kematian. Kematian adalah suatu peristiwa yang nyata dan setiap manusia tidak mungkin dapat menghindarinya, karena hidup dan mati adalah keadaan yang nyata yang harus diterima oleh manusia. Selain itu Plantinga Jr. (2010, p. 318) menjelaskan bahwa kematian selalu merupakan suatu perpisahan. Perpisahan tersebut menurut Plantinga Jr. sering kali menyakitkan, dan ditangisi. Dari pendapat Plantinga Jr., tampak jika 
orang yang mati akan berpisah dengan teman, sahabat, saudara atau keluarganya.

Selain itu, Kantonen (n.d., p. 17) menjelaskan bahwa dalam Perjanjian Baru, kematian seringkali digambarkan sebagai hukuman Allah atas manusia sebagai orang berdosa. Kantonen mencontohkan Roma 6:23 yang berkata “...upah dosa itu maut”. Jiwa atau roh yang ada pada manusia bersifat kekal, sehingga kematian yang dialami oleh manusia bukanlah menunjuk pada kematian jiwa atau roh, namun kematian pada tubuh. Enns (2003, p. 261) menjelaskan bahwa kematian adalah sebuah realitas bagi setiap manusia (Ibr. 9:27). Enns juga menjelaskan bahwa saat Alkitab berbicara tentang kematian, kematian yang dimaksudkan menunjuk pada kematian secara fisik dari tubuh, bukan jiwa. Menurut Enns tubuh manusia boleh mati, tetapi jiwa, prinsip hidup manusia, terus hidup (Mat. 10:28; Luk. 12:4-5).

Kematian merupakan bagian dalam hidup manusia, ketika organ-organ tubuh manusia sudah tidak dapat berfungsi lagi, yang kemudian tubuh itu dikuburkan dalam tanah, sedangkan jiwa masuk dalam alam kekal. Keadaan ini tidak dapat dilepaskan dari kebenaran firman Tuhan yang menyatakan bahwa kematian sebagai hukuman Allah atas manusia yang berdosa. Roh diciptakan oleh Tuhan sebagai kesatuan dari tubuh dan jiwa (Kej.2:7), tapi oleh maut roh itu telah terpisah dari tubuh, Soedarmo (2006, p. 249). Jadi, jelas bahwa kematian akan dialami oleh manusia, baik orang baik maupun orang jahat, karena semua orang telah berdosa dan kehilangan kemuliaan Allah.

Dosa manusialah yang menyebabkan manusia harus mengalami kematian jasmani. Sebelum kejatuhan Adam dalam dosa, Adam tidak mengalami kematian. Tetapi karena dosa Adam yang mencemari manusia keturunannya menjadi orang-orang berdosa pula. Firman Tuhan menegaskan bahwa “... dosa berkuasa dalam alam maut..."; "Sebab upah dosa ialah maut..."; "Sengat maut ialah dosa..." (Thiessen, 2010, p. 520). Dengan demikian sangat jelas dalam firman Tuhan bahwa maut/kematian manusia merupakan akibat dosa manusia, baik dosa yang terjadi akibat kejatuhan manusia pertama (Adam), maupun dosa yang dilakukan oleh setiap manusia di dunia, sebab tidak ada satupun manusia yang tidak berdosa, kecuali Tuhan Yesus yang telah datang ke dunia untuk menyelamatkan manusia dari dosa. Iman di dalam Kristus, yang akan membawa manusia dalam kemuliaan Sorga bersama Tuhan, meskipun secara jasmani manusia tetap mengalami kematian tubuh dalam hidup di dunia ini.

\section{Roh Orang Mati Akan Kembali Kepada Allah}

Alkitab mencatat bahwa roh orang yang sudah mati akan kembali kepada Allah. Di dalam Pengkhotbah 12:7 mencatat bahwa, “... roh kembali kepada Allah yang mengaruniakannya." Dari ayat ini, kata "Allah yang mengaruniakannya" dapat dipahami sebagai 'anugerah Allah', karena roh yang ada pada manusia itu diberikan bukan karena permintaan manusia, melainkan inisiatif dari Allah sendiri. Selain itu, penting juga untuk memahami kata "kembali", karena apa yang telah diberikan oleh Allah akan kembali kepada-Nya. Sehingga, roh yang ada pada manusia akan kembali kepada Allah yang telah mengaruniakannya. Hal itu akan kembali pada Allah apabila sudah waktunya, yaitu saat manusia mengalami kematian atau meninggalkan dunia ini. Mengenai hal ini, Scheunemann (1983, p. 7) mengatakan dalam bukunya bahwa

Sekali Allah memanggil, manusia harus berangkat. Sekali manusia pergi, ia "tidak kembali lagi" (Ayub. 10:21). Roh manusia secara mutlak berada dalam tangan dan kuasa Allah. Tak mungkin ia menunda-nunda waktu atau pun berjalan kian-kemari lagi. Kalau Allah memanggil, manusia pada detik itu juga harus taat untuk menghadap Allah, dan tak mungkin kembali lagi.

Selain itu, Daud juga mengungkapkan dalam Mazmur 104:30 bahwa, “... apabila Engkau mengambil roh mereka, mereka mati binasa dan kembali menjadi debu." Jadi, dari kedua ungkapan ayat di atas, dapat dipahami bahwa segala sesuatu yang diberikan oleh Allah kepada manusia akan kembali kepadaNya, sehingga saat manusia mengalami kematian, rohnya akan kembali kepada Allah yang telah mem- 
berikan roh itu kepada manusia seperti yang terjadi pada awal penciptaannya (bnd. Kej. 2:7).

Jika roh orang mati kembali kepada Allah maka menurut Nubantimo (2015, p. 410) tidak boleh ada penyembahan terhadap roh orang mati. Alasannya menurut Nubantimo adalah Alkitab menolak penyembangan terhadap roh orang mati seperti apa yang dilakukan beberapa orang Kristen yang mengunjungi makam orang yang dikasihinya pada saat-saat menjelang Natal, pergantian tahun, dan juga Paskah.

\section{Tubuh Orang Mati Kembali Kepada Debu Tanah}

Selain roh orang mati kembali kepada Allah, namun Alkitab mencatat bahwa tubuh orang mati akan kembali kepada debu tanah. Sebagaimana yang di tuliskan dalam Kejadian 2:7 bahwa, "Ketika itulah TUHAN Allah membentuk manusia itu dari debu tanah...." Ayat ini menjelaskan bagaimana proses penciptaan manusia, yaitu tubuh manusia itu terbentuk dari debu dan tanah. Oleh karena manusia dibentuk dari debu dan tanah, sehingga pada akhirnya nanti tubuh itu akan kembali kepada keadaan semula, yaitu menjadi debu dan tanah.

Mengenai hal ini, Enns (2003, p. 462) sependapat bahwa karena tubuh manusia diciptakan dari unsur-unsur debu, maka ketika kematian terjadi tubuh manusia pun kembali menjadi debu (Kej. 3:19). Hal ini juga diungkapkan dengan jelas dalam Pengkhotbah 12:7 bahwa, "Dan debu kembali menjadi tanah seperti semula...." Jadi, dapat dipahami bahwa pada saat manusia mengalami kematian, keadan tubuh dan rohnya akan terpisah, karena kematian merupakan perpisahan roh dari tubuh, kemudian perpisahan tersebut tidak lepas dari penderitaan (Ibr. $2: 9 ; 5: 7)$ dan pemisahan roh dari tubuh diakibatkan oleh dosa (Rm. 6:23) dan manusia harus menanggungnya (Scheunemann, 1983, p. 8). Jadi, keadaan tubuh manusia pada saat mati akan kembali kepada debu dan tanah.

\section{Roh Orang Mati Tidak Bergentayangan}

Seperti yang diungkapkan penulis di bagian sebelumnya bahwa, roh orang mati di dalam Tuhan akan kembali kepada Allah, sedangkan roh orang mati yang tidak percaya Kristus akan masuk dalam penghukuman kekal. Artinya ialah saat manusia mengalami kematian, roh manusia tidak akan kembali ke dunia ini karena roh itu akan kembali kepada Allah. Selain itu, tubuh manusia juga tidak akan kembali seperti pada waktu ia masih hidup, karena pada saat mengalami kematian tubuh manusia akan kembali menjadi debu dan tanah. Jadi, jelas bahwa orang yang sudah mati tidak mungkin dapat kembali, bergentayangan (menampakkan diri) dan berkomunikasi dengan orang-orang yang masih hidup, baik keluarga, teman, maupun orang-orang lain.

Dalam Perjanjian Lama, kisah tentang Saul yang memanggil arwah Samuel merupakan suatu peristiwa yang menunjukkan bahwa pemanggilan rohroh nenek moyang bukanlah sesuatu yang dapat dibenarkan dalam firman Tuhan. Raja Saul sangat ketakutan menghadapi orang-orang Filistin (1 Sam. 28: 5), dan dia sangat membutuhkan petunjuk dari Tuhan, walaupun pada kenyataannya Tuhan tidak menjawab ketika dia bertanya kepada Tuhan. Tidak ada petunjuk Tuhan baik melalui mimpi, Urim atau para nabi. Itulah yang mendorong Samuel untuk mencari petunjuk Tuhan melalui pemanggilan arwah (1 Sam. 28:13), “... perempuan itu menjawab Saul: "Aku melihat sesuatu yang ilahi muncul dari dalam bumi." Perempuan itu mengaku adanya roh yang ilahi keluar dari bumi, yang berkenan menemuinya. Namun kebenaran bahwa roh itu berasal dari Allah, tentu harus dianalisis lebih teliti dan mendalam.

Praktik pemanggilan arwah tersebut jelas tidak sesuai dengan kebenaran firman Tuhan, karena ada beberapa alasan yang mendasar: pertama, masalah inkonsistensi Saul dalam melarang dan mempraktikkan praktik pemanggilan arwah tersebut. Pada satu pihak, Saul sendiri yang melarang praktik tersebut dalam hidup umat Israel, Saul menyingkirkan di Israel para pemanggil arwah dan roh peramal (1 Sam. 28:3). Tetapi di lain pihak, Saul juga yang mempraktikkan pemanggilan arwah tersebut secara diam-diam (1 Sam. 28:7-12). Tindakan Saul tersebut menunjukkan ketidak konsistenannya terhadap ma- 
salah tersebut. Padahal larangan untuk memanggil arwah sudah ditegaskan oleh Musa, jauh sebelum Saul hidup (Im. 19:31). Itu artinya larangan mempraktikkan pemanggilan arwah itu yang benar, sedangkan tindakan Saul itu salah, karena tidak sesuai dengan firman Tuhan.

Meskipun perempuan, pemanggil arwah itu mengatakan kepada Saul bahwa "Ada seorang tua muncul, berselubung jubah." (1 Sam. 28:14). Namun hal itu sangat diragukan kebenarannya, karena setan, Iblis juga dapat menyamar sebagai makhluk terang, yang seolah-olah seperti Allah sendiri. Tuhan tidak menghendaki umat-Nya melakukan praktik pemanggilan roh, karena orang yang sudah mati tidak bisa lagi berhubungan dengan orang-orang yang masih hidup. Dalam Perjanjian Lama, konsep tentang keterpisahan antara dunia orang mati dengan orangorang yang masih hidup di dunia juga sudah diajarkan dan ditegaskan.

Kedua, Tuhan sudah undur dari Saul, ketika Saul memanggil roh orang mati (1 Sam. 28:15). Hal itu menunjukkan bahwa praktik pemanggilan roh orang mati, yang dilakukan oleh Saul itu tidak sesuai dengan kebenaran firman Tuhan. Allah sudah undur dari Saul, karena Saul tidak mau taat kepada firman Tuhan (1 Sam. 15:26). Artinya bahwa tindakan Saul itu tidak dalam kehendak Allah. Saul sendiri yang berinisiatif untuk melakukan pemanggilan roh, untuk mendapatkan sesuatu yang diinginkannya.

Ketiga, akhir hidup Saul, yang menunjukkan bahwa Saul tidak dalam keadaan hidup dalam kebenaran firman Tuhan. Saul membunuh dirinya sendiri (1 Sam. 31:4). Itu menunjukkan Saul tidak hidup dalam Tuhan. Dia memaksakan kehendaknya untuk mati karena tidak ingin jatuh di tangan musuhnya.

Dengan memperhatikan alasan-alasan di atas, dapat dimengerti bahwa praktik pemanggilan roh tersebut bukanlah praktik yang benar di hadapan Tuhan. Roh Samuel yang diakui oleh perempuan pemanggil arwah tersebut bukanlah roh nabi Samuel, karena roh orang mati tidak bisa hidup lagi, atau dengan kata lain roh orang mati tidak bisa berhubungan dengan orang yang hidup di dunia ini. Roh orang yang sudah mati tidak bergentayangan diantara orangorang yang masih hidup di dunia ini, sebab dunia orang mati dengan dunia orang yang hidup sudah berbeda, yang tidak mungkin dihubungkan lagi. Jika seolah-olah orang mati bisa datang kepada orang hidup, maka hal itu patut diragukan kebenarannya, karena tidak sesuai dengan kebenaran firman Tuhan.

\section{Tempat Roh Orang Mati}

Pada saat manusia mengalami kematian jasmani (fisik), rohnya akan berada di salah satu tempat yaitu sorga atau neraka. Dalam Alkitab, sorga dan neraka merupakan tempat roh-roh orang yang sudah mati. Sorga merupakan tempat terakhir bagi manusia yang benar, sedangkan neraka merupakan tempat terakhir bagi orang yang jahat atau fasik.

Kata "sorga" dalam bahasa Ibrani adalah 'Shamayim' dan dalam bahasa Yunani 'Ouranos'. Wongso (1993, p. 94) menjelaskan:

Kata "Shamayim"artinya adalah segala udara yang mengelilingi bumi (Atmosfir), tempat dimana semua unggas dapat beterbangan di udara... kadang-kadang menunjukkan ruang angkasa, udara, planet-planet, awan-awan, secara fisik, ada kalanya berbakti tempat tinggal Allah serta para malaikat-Nya.

Dari penjelasan di atas, dapat dimengerti bahwa "Shamayim" menunjukkan suatu eksistensi bagi orang yang sudah mati, yang diperkenan Tuhan. Secara umum, manusia pada jaman dulu (termasuk pada masa Perjanjian Lama) sampai sekarang memahami sorga sebagai suatu tempat yang ada di atas, yang berbeda dengan bumi ini. "Shamayim" dimengerti sebagai tempat tinggal Allah yang penuh dengan kemuliaan Allah. Disitulah tempat orang-orang mati dalam Tuhan tinggal.

Kata 'sorga' dalam bahasa Yunani ialah “ouranos", yang dimengerti suatu tempat tersendiri yang berbeda dengan bumi, tempat di langit (atau bahkan melebihi langit), yang tidak dapat dijangkau manusia, tempat atmosfir di luar angkasa, tempat yang ilahi, tempat tinggal orang-orang percaya, dan tempat dimana Allah hadir (Gingrich dan Danker, 1979, p. 593). Pada prinsipnya pengertian "shama- 
yim" dan "ouranos" sama yaitu menunjukkan suatu tempat yang berbeda dengan bumi, yang jauh di langit - yang tidak mungkin dijangkau oleh manusia, yang tidak dibatasi ruang dan waktu, suatu tempat dimana orang-orang yang percaya dan setia kepada Allah tinggal, sesudah mati. Sorga merupakan eksistensi tersendiri bagi orang-orang yang mati di dalam Tuhan, tempat kediaman Allah dan penuh dengan kemuliaan-Nya.

Dalam bahasa asli Alkitab (Bahasa Ibrani), "neraka" selalu sama artinya dengan musnah, binasa, "destruction" dan kematian (Wongso, 1993, p. 97). Neraka tidak dapat disamakan dengan "sheol" dan “hades", karena neraka merupakan tempat penghukuman kekal. Ada beberapa istilah lain yang digunakan Alkitab untuk menjelaskan tentang 'neraka', yaitu dalam Matius 3:12 mencatat bahwa, “... tetapi debu jerami itu akan dibakar-Nya dalam api yang tidak pernah terpadamkan." Demikian juga dalam Wahyu 21:8, “... mereka akan mendapatkan bagian mereka di dalam lautan yang menyala-nyala oleh api dan belerang ...." Jadi, neraka merupakan suatu tempat penghukuman kekal, dan penggunaan kata neraka sering menjelaskan tentang hukuman bagi orang yang tidak benar atau tidak percaya kepada Tuhan Yesus.

Selain itu, neraka juga merupakan suatu tempat orang-orang yang terpisah dari hadirat Allah (Mat. 7:23, Luk. 13:27 dan 2 Tes. 1:9). Sorga dan neraka merupakan kehidupan di akhirat yang disediakan Tuhan untuk seluruh orang yang sudah mati (Brill, 2015, p. 460). Orang-orang yang mati akan dipisahkan antara yang tinggal di sorga dan neraka. Allah menyediakan sorga khusus bagi orang-orang mati yang di masa hidupnya percaya dan menyembah Kristus. Sebaliknya, neraka disediakan khusus bagi orang-orang mati, yang di masa hidupnya tidak mau percaya kepada Kristus.

Sorga dan neraka merupakan tempat yang disediakan bagi orang-orang yang sudah mati. Sorga merupakan tempat tinggal orang-orang mati yang percaya kepada Kristus, sedangkan neraka merupakan tempat bagi orang-orang mati, yang tidak perca- ya Kristus. Sorga terpisah dari neraka, orang yang di neraka tidak bisa pindah ke sorga, sebaliknya orang yang di sorga tidak bisa pindah ke neraka. Keberadaan masing-masing sudah ditetapkan Allah, dan tidak ada yang bisa mengubahnya. Orang-orang yang sudah ditetapkan Allah di sorga, akan berada di sorga kekal selamanya bersama dengan Allah. Demikian pula, orang yang ditetapkan di neraka, kekal selama-lamanya dihukum dalam nyala api yang tak terpadamkan.

\section{KESIMPULAN}

Dari analisis dan pembahasan di atas sangatlah jelas bahwa teologi Kristen Alkitabiah meyakini kematian merupakan akibat dari dosa manusia. Semua manusia sudah tercemarkan oleh dosa manusia pertama, dan juga dosa yang dilakukan dalam kehidupan ini. Dosa itu menyebabkan manusia cemar di hadapan Allah. Kemuliaan Allah yang ada dalam diri manusia ketika Allah menciptakan manusia pada awalnya, telah hilang akibat dosa. Allah menegaskan bahwa upah dosa itu maut, dan karena semua manusia adalah berdosa, maka semua manusia pasti mengalami kematian jasmani. Kematian dalam hidup manusia adalah kematian jasmani, dimana tubuh manusia kembali kepada debu dan tanah. Jiwa atau roh manusia tidak mengalami kematian, sebab jiwa dan roh itu sifatnya kekal. Kematian manusia menyebabkan jiwa/roh itu masuk dalam dimensi yang lain, yaitu sorga atau neraka.

Bagi orang yang percaya kepada Kristus dalam hidupnya, maka ketika orang itu mati, jiwa/rohnya akan masuk dalam sorga, suatu tempat yang telah disediakan Allah yang begitu mulia, karena Allah ada bersamanya. Sebaliknya, bagi manusia yang tidak percaya Kristus ketika ia hidup, maka jiwa/rohnya akan masuk di neraka, tempat Penghukuman yang tidak pernah berakhir. Ketika seseorang mati, maka rohnya sudah ada dalam dimensi yang lain itu, apakah di sorga atau neraka. Jadi jiwa/rohnya tidak mungkin berhubungan dengan orang yang masih hidup. Sebab jiwa/roh orang yang sudah mati dengan jiwa/roh orang yang masih hidup tidak bisa 
saling berhubungan. Sebab itu, praktik pemanggilan roh orang yang sudah mati, yang biasa dilakukan oleh dukun, dalam budaya tertentu tidak sesuai dengan kebenaran firman Tuhan. Alkitab menegas-

\section{DAFTAR RUJUKAN}

Brill, J. W. 2015. Dasar Yang Teguh. Bandung: Kalam Hidup.

Dyrness, W. 2013. Tema-tema dalam Teologi Perjanjian Lama. Malang: Gandum Mas.

Ebenhaizer I. Nuban Timo, 2015. Allah Menahan Diri Tetapi Pantang Berdiam Diri. Jakarta: BPK Gunung Mulia, 2015.

Enns, P. 2003. The Moody Handbook Of Theology. Malang: SAAT.

Gingrich, F. Wilbur \& Danker, Frederick W. A Greek-English Lexicon of the New Testament. Chicago: The University of Chicago Press, 1979.

Hoekema, A. A. 2003. Manusia: Ciptaan Menurut Gambar Allah. Surabaya: Momentum.

Hunt, Gladys. 1987. Pandangan Kristen Tentang Kematian. Jakarta: Gunung Mulia.

Kantonen, T. A. n.d. Apakah Yang Terjadi Sesudah Mati? Bandung: Literatur Baptis.

Kruyt, A. C. 2008. Keluar Dari Agama Suku Masuk Ke Agama Kristen. Jakarta: Gunung Mulia.

Lakburlawal, G. S. 2017. "Ma'badong: Pemahaman Gereja Toraja Jemaat Lean terhadap Ma'badong." Skripsi, Program Studi Teologi FTEO-UKSW. http://repository.uksw.edu/ handle/123456789/13396

Paterson, R. M. 2011. Tafsiran Alkitab: Kitab Imamat. Jakarta: Gunung Mulia. kan bahwa orang yang sudah mati, jiwa/rohnya akan ke sorga atau ke neraka, dan tidak bisa berhubungan dengan orang yang hidup.

Phillips, Mc C. 1972. Dunia Roh. Bandung: Kalam Hidup.

Plantinga Jr, C. 2010. Jaminan Iman: Devosi Pembangunan Iman. Surabaya: Momentum.

Salam, Rahayu. 2017. "Ma' Badong Ritual in Tana Toraja." https://kebudayaan.kemdikbud.go.id/bpnbsul sel/ritual-mabadong-di-tana-toraja/

Scheunemann, V. 1983. Dunia Orang Mati. Malang: Yayasan Persekutuan Pekabaran Injil Indonesia.

Soedarmo, R. 2006. Ikhtisar Dogmatika. Jakarta: Gunung Mulia.

Strong, J. 1980. Strong's Exhaustive Concordance Complete And Unabridged. United States of America: Baker Book House.

Tago'a, J. \& Enoh, I K. 2010. “Tinjauan Teologis Terhadap Budaya Pemanggilan Arwah Orang Mati Pada Suku Pamona." Jurnal Jaffray, 8 (2): 23-34. http://dx.doi.org/ 10.25278/jij1.v8i2.44

Thiessen, H. C. 2010. Teologi Sistematika. Malang: Gandum Mas.

Walangare, T. 2016. "Kajian Teologi Roh Orang Sesudah Mati Dimasa Antara (intermediate state) Dalam PAK", Jurnal Educatio Christi, XXI (24): 65-76.

Wongso, P. 1993. Dasar Iman Kepercayaan Kristen. Malang: Literatur SAAT. 